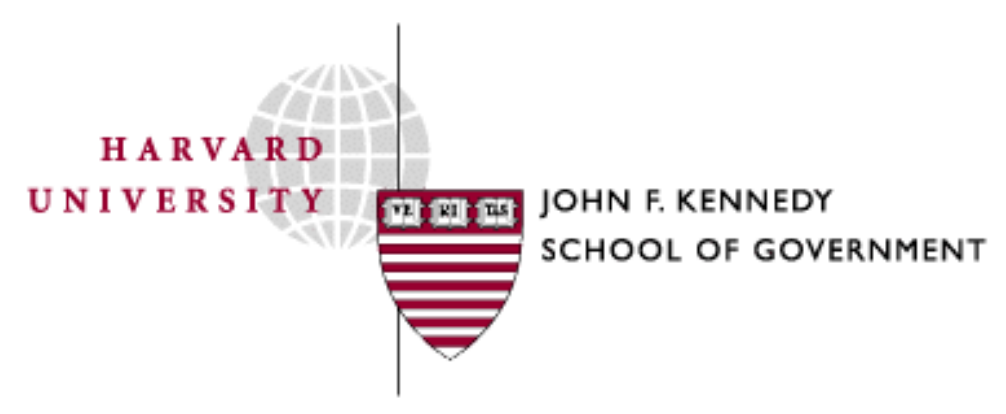

Faculty Research Working Papers Series

\title{
Giving Green to Get Green: \\ Incentives and Consumer Adoption of Hybrid Vehicle Technology
}

\author{
Kelly Sims Gallagher and Erich Muehlegger \\ John F. Kennedy School of Government - Harvard University
}

February 2008

RWP08-009

The views expressed in the KSG Faculty Research Working Paper Series are those of the author(s) and do not necessarily reflect those of the John F. Kennedy School of Government or of Harvard University. Faculty Research Working Papers have not undergone formal review and approval. Such papers are included in this series to elicit feedback and to encourage debate on important public policy challenges. Copyright belongs to the author(s). Papers may be downloaded for personal use only. 


\title{
Giving Green to Get Green? Incentives and Consumer Adoption of Hybrid Vehicle Technology
}

January 2008

\author{
Kelly Sims Gallagher and Erich Muehlegger ${ }^{1}$
}

\begin{abstract}
Federal, state and local governments use a variety of incentives to induce consumer adoption of hybrid-electric vehicles. We study the relative efficacy of state sales tax waivers, income tax credits and non-tax incentives and find that the type of tax incentive offered is as important as the value of the tax incentive. Conditional on value, we find that sales tax waivers are associated a seven-fold greater increase in hybrid sales than income tax credits. In addition, we estimate the extent to which consumer adoption of hybrid-electric vehicles (HEV) in the United States from 2000-2006 can be attributed

to government incentives, changing gasoline prices, or consumer preferences for environmental quality or energy security. After controlling for model specific state and time trends, we find that rising gasoline prices are associated with higher hybrid sales, although the effect operates entirely through sales of the hybrid models with the highest fuel economy. In total, we find that tax incentives, rising gasoline prices and social preferences are associated with 6, 27 and 36 percent of high economy hybrid sales from 2000-2006.

\footnotetext{
${ }^{1}$ Both authors are from the John F. Kennedy School of Government, Harvard University, Cambridge, MA. Gallagher directs the Energy Technology Innovation Policy research group and is Adjunct Lecturer of Public Policy and Muehlegger is an Assistant Professor of Public Policy. Our research benefited from conversations with Robert Stavins, Richard Zeckhauser, Meghan Busse, Tie Gao and seminar participants at the UC Berkeley Energy Institute, Yale Environmental Economics Conference and the Kennedy School of Government. Funding was provided by the U.S. Environmental Protection Agency, William and Flora Hewlett Foundation, the Energy Foundation and the Kennedy School's Institute of Politics. Excellent research assistance was provided by Fanny Chen and Jaclyn Marks. We thank the Sierra Club for providing data on their membership.
} 


\section{Introduction}

Hybrid-electric vehicles contain a unique power train that combines a gasoline engine with an electric motor and battery system. A hybrid-electric engine consumes less gasoline and emits less pollution per mile than a traditional internal combustion engine with similar performance. As such, hybrid-electric vehicles can have substantial public benefits for both the environment and for energy security. Accelerated domestic adoption of hybrid-vehicle technology plays an important role in the debate over strengthening or reforming Corporate Average Fuel Economy (CAFE) standards as well as design of new climate change policies.

Beginning in 2000, federal, state and local governments implemented a broad set of incentives to stimulate consumer adoption of hybrid technology. ${ }^{2}$ States offer a variety of incentives including income tax credits and deductions, waivers of state sales tax, single-passenger access to high-occupancy vehicle (HOV) lanes, and waivers of fees for registration, emissions testing, excise and parking. Many incentives are generous, worth several thousand dollars and reduce the incremental cost associated with purchasing a hybrid vehicle. Subsequently, domestic sales of hybrid vehicles increased substantially. In 2000, the Honda Insight and Toyota Prius were the only hybrid vehicles available and collectively sold fewer than 3,000 units. Over the next six years manufacturers introduced nine other models. Honda launched hybrid versions of the Civic and Accord in 2002 and 2004, and Ford introduced a hybrid version of the Escape

\footnotetext{
2 The federal government has also supported the research, development, and demonstration of hybrid vehicles for many years. Although this paper does not investigate the impact of government investments into hybrid-vehicle technology at the R\&D stage, the federal government has devoted substantial resources to the development of hybrids through the Partnership for a New Generation of Vehicles (PNGV) and its successor, FreedomCAR, as well as through specific hybrid-electric vehicle R\&D programs. In fiscal year 2008, for example, the President's budget request to Congress for HEVs was \$80 million.
} 
small SUV. In 2005, the Lexus RX400h, Toyota Highlander, and Mercury Mariner were launched, and in 2006, the Lexus GS450H, Saturn Vue, and Toyota Camry hybrid debuted. Sales have risen substantially - by 2006, more than 250,000 hybrid vehicles were sold.

The observed pattern of sales is consistent with a model of technology adoption in which consumers initially have imperfect information about hybrid vehicle technology. At the beginning of the period, sales are low - consumers lack information about the quality, performance and durability of new hybrid vehicle technology. Only individuals with a strong preference for hybrid vehicle technology or a high estimate of the quality of hybrid vehicles choose initially adopt. Gradually, other consumers either observe the quality of new technology or infer the quality of new technology by assuming that the early adopters have made good choices. Consumer adoption can be further delayed if automakers learn from consumers experience and improve the quality of successive model-years or if the provision of hybrid-oriented services (e.g. service stations familiar with hybrid technology) is a function of the installed base of vehicles.

In this paper, we study the extent to which the recent consumer adoption of hybrid vehicle technology can be attributed to government incentives, changes in gasoline prices, and social preferences for environmental quality or energy security. We estimate the relative impacts of three factors contributing to consumer adoption of hybrid automobiles: (1) incentives offered by state governments (including tax incentives and single occupancy access to HOV lanes), (2) market incentives created by changes in gasoline price, and (3) social preferences for environmental quality or energy security. We study the not only the generosity of government incentives, but also the form of 
government incentives offered. We differentiate between tax credits and sales tax incentives and find that the latter are associated with a greater increase in hybrid sales, consistent with the results in Chetty, Kroft and Looney (2007) and Finkelstein (2007) who find consumer response to taxation varies with the salience of the tax.

A growing literature on vehicle purchase decisions study related questions, although we believe our paper to be unique in studying all three in the context of technology adoption. Sallee (2007) studies the incidence of state and federal tax incentives offered to Prius owners using consumer-level purchase data. His central finding is that the majority of state and federal incentives are captured by consumers, rather than producers. In addition, using a differences-in-differences approach, he estimates dynamic consumer response to changing incentive generosity and finds that a fraction of consumers time Prius purchases contemporaneously with generous incentives. Rather than focusing on the dynamic considerations, we estimate relative demand response to state income tax credits and state sales tax exemptions for the entire set of hybrid vehicles offered over the period.

There is growing evidence that consumers will respond to higher energy prices, even if they do not rationally calculate how long it will take to pay back when deciding whether or not to purchase a more expensive energy-efficient product. Newell, Jaffe, and Stavins (1999), for example, find that energy prices, product labeling, and government standards all boost energy efficiency in products such as air conditioners and gas heaters. In the context of gasoline and automobile sales, Bento, Goulder, Jacobsen and vonHaefen (2006), Klier and Linn (2007), and West (2007) study the relationship between gasoline prices and consumer decisions from a structural perspective and find similar results, that 
consumers tend to incorporate the per mile cost of vehicles into their purchase decisions. We estimate the cross-price elasticity of automobile demand to tax-inclusive gasoline price using a reduced form methodology and allow the elasticity to vary by mileage as well as consumer travel intensity.

Finally, a few papers consider the impact of personal beliefs or social preferences on hybrid technology adoption. Kahn (2006) finds that growth in the number of environmentalists and their willingness to pay for more costly environmental products creates market demand for producers who are developing more costly green products. Studying HEV purchases in Los Angeles country, Kahn finds that initial hybrid penetration in California occurred predominantly in census tracks with greater than average environmental preference, as measured by the percentage of registered green party voters. Later penetration occurred in nearby census tracks that experienced increases in gasoline prices. Turrentine and Kurani (2007) find a similar evidence, albeit anecdotal, through a limited survey of early hybrid vehicle adopters in California - many stated that they were primarily motivated by non-economic considerations such as being a pioneer, an environmentalist, or just "living lighter" - in other words, and did not perceive a specific price difference that they had paid for their HEV. There may be an additional motivation for consumers to purchase hybrids in that they allow one to vividly demonstrate one’s commitment to environmental protection or energy security.

To estimate the extent to which consumer adoption of hybrid-electric vehicles in the United States from 2000-2006 can be attributed to government incentives, changing gasoline prices, and social preferences for environment quality or energy security, we use data on quarterly state-level hybrid sales from JD Power and Associates. We estimate 
our model using model*time and model*state fixed effects and exploit withinstate*model variation in incentives, gasoline prices and metrics for consumer ideology to estimate the coefficients of our model. Our paper makes several contributions to the existing literature on the effect of government incentives to accelerate deployment of advanced technologies. To our knowledge, it is the first comprehensive study of the effect of hybrid tax incentives, gasoline prices, and consumers' social preferences on hybrid vehicle adoption. We estimate that tax incentives, rising gasoline prices and social preferences increased hybrid sales 6, 27, and 33 percent respectively. We further attribute approximately 54 percent of hybrid sales over the period to this combination of factors.

Moreover, our work also has important implications for future hybrid vehicle policy specifically, as well as how the government should induce consumer adoption of other energy efficient products. First, we find that different types of state incentives differ substantial in their efficacy. Although the generosity of the incentive is positively correlated with hybrid sales, sales tax waivers for hybrid vehicles are associated with a much larger effect on demand than state income tax credits conditional on generosity. We estimate that a sales tax waiver of mean value $(\$ 1,037)$ is associated with more than twice as large a demand effect as a tax credit of mean value $(\$ 2,011)$. Second, we find that gasoline prices affect hybrid vehicle adoption decisions, although the effect operates almost entirely through adoption of hybrids with high fuel economy. For high fuel economy hybrids, our point-estimate for the cross price elasticity of demand with respect to retail gasoline price is 0.86 . Finally, we find that proxies for social preferences for 
environmental quality and energy security are positively correlated with adoption of high economy hybrid vehicles.

We first summarize the set of federal, state, and local hybrid incentives. We then discuss our data and empirical methodology and present our results. We conclude by discussing the policy implications.

\section{Background}

The hybrid electric engine combines a gasoline engine and electric motor to substantially improve technical fuel efficiency. ${ }^{3}$ Automakers can design HEVs to use the energy savings from the additional efficiency to improve fuel economy or to enhance performance. Although hybrid passenger vehicles vary along this performance/fueleconomy continuum, models can be broadly classified as either: (1) “strong” hybrids models with substantially greater fuel economy relative to similar cars in the class, and (2) “mild” hybrids - models with modest improvements in fuel economy, but increased performance. For example, the combined city-highway EPA fuel-economy rating for the “strong” 2007 Civic hybrid (1.3 liter engine) was 42 miles per gallon, while the combined fuel-economy rating for the least powerful non-hybrid version of the Civic (1.8 liter engine) was 29 miles per gallon. In comparison, the combined fuel-economy rating for the “mild” 2007 Accord hybrid (3.0 liter engine) was 27 miles per gallon while the least powerful non-hybrid version (2.4 liter engine) was rated at 25 miles per gallon. ${ }^{4}$

\footnotetext{
${ }^{3}$ We define fuel efficiency to mean the technical fuel efficiency of the vehicle - the energy at the wheels divided by the energy in the tank whereas fuel economy is defined as total miles traveled by a vehicle divided by total fuel use.

${ }^{4}$ See www.fueleconomy.gov.
} 
In addition to the fuel economy and performance benefits, HEVs have substantial environmental benefits. Because all hybrids are at least somewhat more fuel-efficient, they inherently reduce climate-altering greenhouse-gas emissions. Also, with the exception of the Saturn Vue, all hybrids on the market today are very low-emission vehicles in terms of conventional tailpipe air pollution. Most HEVs qualify as "superultra low-emission vehicles” (SULEVs), and all but the Saturn Vue receive a rating of 8 or better in EPA's air pollution index. Thus, hybrids are capable of reducing urban air pollution, reducing U.S. oil consumption (and thereby enhancing U.S. energy security), and reducing greenhouse-gas emissions from the U.S. transportation sector.

Due to the potential environmental and energy security benefits, the U.S. federal, state and local governments provides incentives for consumer hybrid vehicle purchases. The federal government initially offered a $\$ 2,000$ tax deduction for HEVs beginning with sales of model year 2000 Honda Insights. In subsequent years, the Internal Revenue Service certified all other newly-introduced hybrid electric vehicles as being eligible for the clean-fuel deduction. The deduction was converted into a full tax credit under the Energy Policy Act of 2005. Effective January, 2006, the tax credit is more generous than the previous tax deduction and varies by model, depending on the emissions and fuel economy. ${ }^{5}$ The Toyota Prius qualifies for the largest tax credit $(\$ 3,150)$ while Accord Hybrids and the Saturn VUE Green Line qualify for the lowest tax credit (\$650). After a carmaker sales exceed 60,000 units, the credit phases out over the next four quarters.

\footnotetext{
${ }^{5}$ Although the tax credit is more generous than the tax deduction for most individuals, the tax credit has no effect on a filer's tax owed under the Alternative Minimum Tax. For filers subject to the AMT, the federal credit creates no additional incentive. Also, if the filer is eligible for multiple tax credits, the hybrid tax credit is taken last after all the other credits (e.g., child care tax credit, mortgage credit, and retirement savings credit) have been taken. Any tax liability left over by these reductions will be the maximum dollar limit of the hybrid tax credit.
} 
After meeting the sales limit, the credit for all models produced by the carmaker falls in half for two quarters and then to 25 percent for the next two quarters, after which the credit expires. To date, only Toyota has exceeded the 60,000 unit threshold. In May 2006, Toyota surpassed the threshold. The tax credits for Toyota models were cut in half after September 30, 2006, and fully expired October 1, 2007.

State and local governments offer a wide variety of incentives. Table 1 presents a comprehensive list of state-level HEV incentive programs offered during 2000-2006. Twelve states offered a tax incentive, either in the form of an income tax credit or a sales tax waiver at some point during 2000-2006. ${ }^{6}$ The generosity of tax incentives varies substantially by state, model and time. For example, income tax credits for the Prius vary from $\$ 630$ in South Carolina to over \$3,500 in Colorado and West Virginia. Connecticut and the District of Columbia fully waive the $6 \%$ sales tax on Hybrid vehicles purchases (worth approximately $\$ 1,300$ ) and New Mexico partially waives the sales tax on hybrid vehicle sales (worth approximately $\$ 650$ ). Pennsylvania offers a rebate of between $\$ 300$ and $\$ 500$ for purchases of some models. Five of the twelve states offered incentives for the purchase of high economy hybrid vehicles only. Conditional on offering a state tax incentive, the mean values of the income tax credit and sales tax exemption are \$2,011 and $\$ 1,037$, respectively.

A number of states offer other incentives for hybrid purchases. Virginia, California, Utah, New Jersey, and Florida allow single-occupancy hybrid vehicles to travel in high-occupancy vehicle (HOV) lanes. Virginia has allowed all hybrid vehicles

\footnotetext{
${ }^{6}$ Colorado, Maryland, Oregon and South Carolina currently offer an income tax credit for hybrid vehicle purchases. Utah, New York and West Virginia had tax credits that expired. Connecticut, the District of Columbia and New Mexico exempt (partially in the case of New Mexico) hybrid purchases from state sales taxes. Sales tax exemptions expired in Maine and New York as well. Finally Pennsylvania offers a rebate for the purchase of some hybrid models.
} 
to travel in HOV lanes since 2000. Recently, in response to increased congestion on I95/395 HOV-3 lanes (which require 3, rather than 2, passengers in a car), Virginia restricted hybrid travel in HOV-3 lanes during rush hour beginning on July 1, 2006. HOV incentives in Virginia are currently renewed on an annual basis and set to expire June 30, 2008. California's program is more recent and limited in scope. Beginning in August 2005, California issued 85,000 permits allowing owners of hybrids meeting stringent emissions qualifications and achieving fuel economy ratings of greater than 45 miles per gallon to travel single occupancy in HOV lanes. In practice, California's regulations restrict permits to owners of the Prius, Civic Hybrid, and Insight. Utah allows all hybrid vehicle owners to purchase special license plates, allowing single-person travel in HOV lanes. Finally, in 2006, New Jersey (Q2) and Florida (Q3) opened HOV lanes to single-occupancy hybrid vehicles on some routes. In addition to the current programs, pilot programs allowing single occupancy in HOV lanes run in New York and Arizona. Colorado and Georgia have passed HOV lane exceptions for hybrid vehicles, but are awaiting a federal ruling on HOV access. In addition, three states reduce or eliminate registration or excise taxes. Three states provide vehicle emissions test exemptions for hybrid vehicles. Four states have government purchasing requirements. At the local level, a number of cities (e.g. San Jose, Baltimore, Albuquerque, and New Haven) reduce or waive public parking fees for hybrid electric vehicles.

Finally, some corporations have begun to provide generous private incentives for employee hybrid vehicle purchases. Beginning in 2004, for example, Timberland offered a $\$ 3,000$ rebate towards hybrid purchases. Google began to offer a $\$ 5,000$ rebate for 
hybrid vehicle purchases in March 2005, and Bank of America began to offer a $\$ 3,000$ rebate for hybrid vehicle purchases in June 2006.

In addition to existing federal, state, local, and private-sector incentives, market incentives, in the form of higher gasoline prices, may be partially responsible for the consumer adoption of hybrid vehicles between 2000 and 2006. Average U.S. taxinclusive retail gasoline prices increased from $\$ 1.49$ per gallon over 2000-2003 to $\$ 1.89$ per gallon in 2004, \$2.31 per gallon in 2005 and \$2.61 per gallon in 2006. ${ }^{7}$ If consumers choose vehicles based partially on their expectation of future operational costs, a consumer's preference for greater fuel economy would be positively correlated with local gasoline prices. So long as the substitution towards more fuel efficient vehicles outweighs the income shock associated with rising gasoline prices, we expect that consumers would be more likely to purchase hybrid vehicles when gasoline prices increase. We would also expect that the incentive effect of gasoline prices would be greatest for "strong” or high-fuel-economy hybrid vehicles, for which the fuel savings are greatest.

\section{Data and Methodology}

We use quarterly state-level data on sales of each hybrid model to distinguish the impact of three factors which potentially speed consumer adoption of hybrid technology: (1) government incentives, including single occupancy HOV lane access and income or sales tax incentives, (2) changes in gasoline prices, and (3) changes in consumer travel intensity or preferences for environmentalism or national security. Our study period runs

\footnotetext{
${ }^{7}$ Although our data does not cover 2007, this trend has continued in 2007. Average U.S. tax-inclusive gasoline price from January 1 through September 24 is $\$ 2.78$ per gallon.
} 
from Q1 2000 to Q4 2006 during which automakers introduced eleven hybrid models. The date at which domestic sales first appear in the JD Power data are: Honda Insight (2000Q1), Toyota Prius (2000Q3), Honda Civic (2002Q1), Honda Accord (2004Q4), Ford Escape (2004Q3), Lexus RX400h (2005Q1), Toyota Highlander (2005Q2), Mercury Mariner (2005Q3), Lexus GS450h (2006Q2), Toyota Camry (2006Q2) and Saturn VUE (2006Q4). To allow for each model to have its own time trend and different attractiveness to each state's population, we include both state*model and time*model fixed effects, and estimate the model using within-state*model variation in trend of sales.

We purchased our data on hybrid sales from JD Power and Associates. The sales data is based on their proprietary Power Information Network data. The Power Information Network (PIN) collects real-time transaction level data from approximately 6,000 dealers. For our analysis, JD Power and Associates aggregated consumer purchases (as opposed to fleet purchases) in the PIN transaction data up to quarterly quantities for each model at the state level. Based on actual purchases, the transaction data provides more accurate timing information than vehicle registration data. For our analysis, JD Power limited the sample to consumer purchases. This excludes private and government fleet purchases which at best are unrelated to consumer preferences and at worst are correlated with state government incentives. The exclusion of these sales ensures that we will not misattribute government purchases to state consumer incentives. ${ }^{8}$

We classify models as high fuel-economy hybrids if the EPA-rated fuel economy is 50 percent greater than other vehicles in its class. Using this criterion, we classify the

\footnotetext{
${ }^{8}$ Even if government sales are included, we would not expect substantial bias. Government purchases uncorrelated with consumer incentives would conservatively bias our estimates. Even if unobserved government purchases are correlated state-level incentives, publicized government purchases are small relative to consumer purchases.
} 
Honda Insight and Civic, Toyota Prius and Camry and the Ford Escape as high fueleconomy vehicles. ${ }^{9}$ Figure 1 graphs quarterly domestic sales of high and low fueleconomy hybrids as well as the average quarterly retail price of gasoline reported by the Energy Information Administration (EIA) from Q1 2000 until Q4 2006. Honda and Toyota introduced high-economy hybrids first, beginning with the Insight, Prius and Civic. Due to earlier introduction dates, sales of high-economy hybrid models account for the vast majority of total hybrid sales from Q1 2000 to Q4 2006. ${ }^{10}$ Over 2005 and 2006, though, sales of lower efficiency models increase substantially accounting for 28 percent of the 182,000 hybrid sales in 2005 and 25 percent of the 235,000 hybrid sales in 2006. Interestingly, sales of all models fall in the final quarter of 2005. Although only anecdotal, this may be the result of the change in federal tax incentives on January 1, 2006. Consumers may have chosen to delay hybrid purchases in Q4 of 2005 in anticipation of the more generous federal tax credits. ${ }^{11}$

Our dataset of state and federal incentives programs were collected by contacting regulators in each jurisdiction. Although a large number of incentive programs exist, we focus specifically on incentives related to high-occupancy vehicle (HOV) lane access and tax incentives. We omit local incentive programs such as parking fee waivers and state vehicle registration incentives since both are likely of insufficient magnitude to affect state-level sales of hybrid vehicles substantially. We construct quarterly average taxinclusive retail gasoline price for each state, based on monthly gasoline price data from

\footnotetext{
${ }^{9}$ In our analyses, we also test a second economy criterion: whether EPA-estimated fuel economy exceeds forty-five miles per gallon, classifying the Honda Insight and Civic and the Toyota Prius as high-economy. The use of the alternative classification does not substantively affect any of our empirical conclusions.

${ }^{10}$ Total hybrid sales in the JD Power data total 554,657 units from Q1 2000 until Q4 2006. Sales of high efficiency models total 445,342 units over the period.

${ }^{11}$ Although our inclusion of model*time fixed effects precludes testing this hypothesis, Sallee (2007) exploits the timing of taxation changes to study dynamic consumer response to expected changes in incentive generosity.
} 
the Energy Information Administration. We also include state-level demographic controls from the Current Population Survey. We use the percent of residents with a high school or four-year college diploma, per capita income, mean age and proportion female.

Finally, we construct proxies capturing consumer travel behavior and preferences for environmental quality and energy security. As a proxy for travel intensity, we use annual per-capita vehicle-miles traveled in each state. We also use average commuting time as an alternative - the choice of proxy for travel intensity does not change our empirical conclusions. We use state-level per-capita Sierra Club membership as a proxy for the proportion of a state's population with a high preference for environmental activism. As proxies for the salience of global warming and anti-war sentiment, we use quarterly deviation from 100-year average temperatures, per-capita armed forces participation, and per-capita casualties in Iraq and Afghanistan.

Table 2 presents the summary statistics for the hybrid sales data, gasoline prices, state and federal incentives, and socioeconomic measures. We use the unbalanced panel to generate the summary statistics for hybrid sales and state incentives. For demographics and gasoline prices, we treat each state-quarter as a single observation and report the summary statistics for the balanced panel. Conditional on positive sales, mean model sales in a particular state-quarter are 121.1, with a high of 8,871 for Prius sales in California in Q3 2006. Approximately 94 percent of hybrid sales over the study period are eligible for a federal tax incentive with a mean value of $\$ 1,073$. Twelve percent of hybrid sales are eligible for either a state income tax or sales tax incentive, with average values of $\$ 2,011$ and $\$ 1,037$ dollars respectively. During the sample period, mean tax- 
inclusive retail gasoline is $\$ 1.80$ gallon with a low of \$0.994 a gallon (Georgia, Q4-2001) and a high of \$3.10 a gallon (Hawaii, Q3-2006).

In the empirical section, we estimate the effect of government hybrid incentives, retail gasoline prices, and social preferences on hybrid sales. We first estimate and compare the effects of government incentives designed to stimulate purchases and market incentives created by changed gasoline prices. We evaluate a number of testable hypotheses related to relative sales of high-economy and low-economy hybrids. In particular, we would expect rising gasoline prices to have an especially large effect on the sales of higher efficiency hybrid models, models for which the relative fuel economy improvement over similar cars is substantial. In addition, we expect that the fuel efficiency and lower emissions of higher efficiency models would be particularly attractive to individuals with a strong preference for the environment or energy security and individuals with higher travel intensity. We then study how incentive efficacy relates to the structure of the tax incentive provided. We compare the effect of sales tax waivers and income tax credits and find, consistent with the literature on tax salience, that sales tax waivers are associated with significantly greater sales than income tax incentives. Finally, we test whether proxies for environmental preferences or preferences for energy security are correlated with sales of high economy hybrids, for which the environmental and energy security benefits are the greatest.

To estimate the relationship between hybrid sales and gasoline prices, state and federal incentives and socioeconomic measures, we run a fixed effects panel regression using both state and model*time fixed effects. Our approach regresses the log of per capita sales of model $\mathrm{m}$ in state $\mathrm{i}$ at time $\mathrm{t}$ on logged gasoline price, hybrid incentives, 
state demographics and a set of fixed effects. Indexing state, model and time as $\mathrm{i}, \mathrm{m}$ and $\mathrm{t}$ respectively, our base specification is given by

SalesPerCapita $_{i m t}=\alpha_{i m}+\beta$ Gasprice $_{i t}+\lambda$ Incentives $_{i m t}+$ ODemographics $_{i t}+\eta_{m t}+\varepsilon_{i m t}$

where $\alpha_{\text {im }}$ denotes the state*model fixed effects, $\eta_{\mathrm{mt}}$ denote the time*model fixed effects and $\varepsilon_{\text {imt }}$ denotes the stochastic error term. We include time*model fixed effects to control for the mean pattern of sales for each model. The time*model fixed effects provide a flexible parameterization to capture state-invariant trends in sales, national production constraints, and the timing of each model's introduction. The state*model fixed effects control for model-specific time-invariant unobservables at the state-level. That is, if Massachusetts consumers have an consistent preference for the Toyota Prius relative to the Honda Civic hybrid, mean preferences are captured by the state*model fixed effects. In our base econometric specification, identification comes from cross-state variation in model-level sales trends.

In addition, we decompose the state*model fixed effects into a state preference for hybrid vehicles, preferences for higher economy models from our correlated with our proxies for environmentalism or energy security salience and an unobservable component. That is, we consider the equation given by

$$
\begin{aligned}
\text { SalesPerCapita }_{i m t}= & \phi_{i} \\
& +\gamma \text { HighEff }_{m} * \text { proxies }_{i} \\
& +\beta \text { Gasprice }_{i t}+\text { Incentives }_{i m t}+\text { ODemographics }_{i t}+\eta_{m t}+\varepsilon_{i m t}
\end{aligned}
$$


Several sources of potential bias exist arising from the endogeneity of state incentives and gasoline prices. States may choose which incentive to offer based on the relative efficacy of the different incentives in a particular state. For example, California and Virginia may choose to allow hybrid vehicles to access the HOV lanes because travel/traffic costs are significant in each of these markets. More rural locations where travel/traffic costs are substantially lower may choose to use tax incentives instead. Endogeneity of this form lead our point estimates to be upper bounds on the efficacy of government incentives. State gasoline prices, on the other hand, are plausibly exogenous to hybrid sales. Although high-economy hybrids are substantially more fuel efficient than comparable non-hybrid vehicles, hybrid market penetration is fairly low during the study period. Thus, hybrid vehicles account for a small share of total gasoline consumption and are unlikely to affect state gasoline prices.

In several quarters in 2002 and 2003, production limitations constrained sales of the Toyota Prius and Honda Civic hybrid. If production constraints affected all states equally, our use of time*model fixed effects would control for state-invariant scarcity. If automakers allocated a greater proportion of production during periods of scarcity to states with more generous incentives, though, we may inappropriately attribute the effect of production constraints to the government incentives. We believe that this concern does not substantively bias our results. Our conversations with Toyota indicate that the firm allocated scarce production so as to equalize the delivery delays across the different markets. To the extent that the sales of hybrid vehicles during these periods was proportional to existing demand, model*time fixed effects will capture the effect of production constraints. We econometrically confirm this by test the robustness of our 
estimates to the exclusion of periods in which model production exceeded production limits. We find the exclusion of these quarters does not substantively change our empirical conclusions.

Finally, we observe model level sales, but do not observe the negotiated price between the dealer and the consumer. Thus, we cannot observe the dealer incentives offered, nor can we observe how the dealer and consumer split the tax incentive. Our fixed effects control for state invariant correlation of dealer incentives and state incentives. Although Sallee (2007) finds strong evidence that consumers retain the vast majority of the hybrid tax incentives, if the benefits of state incentives are partially captured by dealers, either from negotiation or through endogenous dealer incentives, we would again conservatively bias our estimates of the benefits of state-level incentives.

\section{Results}

Table 3 presents the estimated coefficients for our econometric model. We regress the log of per capita sales on state demographics, the log of tax-inclusive gasoline prices, the dollar value of tax incentives, and a dummy variable for single occupant access to HOV lanes. Specification (1) estimates our base model using state and time*model fixed effects, while specifications (2) through (7) use the full set of state*model and time*model fixed effects. Using state*model and time*model fixed effects we estimate our coefficients off cross-state variation in the sales trends of particular hybrid models. Although we present the first specification using state fixed effects, we focus our discussion on specifications (2) through (7), which use state*model and time*model fixed effects. 
Specification (2) presents our base econometric results. Specification (3) and specification (4) replace the dollar value of tax incentives with the value of tax incentives as a proportion of model-year MSRP and a dummy variable for a state offering some form of tax incentive for the particular model, respectively. Specification (5) separates the dummy variable for HOV access by state. In specification (6), we separately estimate the effects of gasoline price on high and low-economy hybrids. We expect that increasing gasoline prices would have a greater effect on the purchases of hybrid vehicles with high fuel economy. In specification (7), we further relax how gasoline price affects the sales of high and low-economy hybrids by interacting gasoline prices for high and low-economy models with annual per capita vehicle miles traveled in each state. In addition to the hypothesis that demand for high-economy hybrids will respond more to an increase in gasoline prices, we would expect that consumer response to increasing gasoline price would be greater in high mileage states.

Our estimated coefficients on demographic variables are robust across the different specifications. We find that per-capita income and mean age are significantly correlated with hybrid sales. We estimate that the point estimate for income elasticity is approximately 2.1 - a one-standard deviation increase in per-capita income is associated with a 24 percent increase in hybrid sales. In addition, we find that hybrid sales are negatively correlated with the mean age. Coefficients on gender and educational attainment are not statistically significant in our initial specifications.

The coefficient on the value of state tax incentives is positive and significant across all specifications using state*model and time*model fixed effects. ${ }^{12}$ We estimate

\footnotetext{
${ }^{12}$ We omit a variable for federal tax incentives from our regressions - federal tax incentives do not vary by state and are subsumed by our set of model*time fixed effects. Aggregating federal incentives with state
} 
that offering a tax incentive which is $\$ 1000$ more generous is associated with a 5 percent increase in the demand for a hybrid model. When measured relative to model MSRP, we find that increasing a tax incentive by 1 percent is associated with a 1.06 percent increase in per capita hybrid sales. In specification (5), we estimate that offering a tax incentive at the mean value in our sample is associated with a 17 percent increase in demand for a hybrid vehicle.

We find little evidence that allowing single occupancy travel HOV lane access has a significant impact on hybrid vehicle sales. When we separately estimate coefficients for each state's HOV program, we find that the effects of HOV access vary by state. We also allow for the effect of HOV access in Virginia to vary before and after rush hour HOV-3 lane restrictions and find a statistically significant difference between the effects of HOV access before and after the restriction. Prior to the HOV-3 restriction, HOV access in Virginia is associated with a $65 \%$ increase in hybrid sales. Although large, this is consistent with anecdotal evidence suggesting that a large proportion of hybrid owners took advantage of HOV-3 access during this period. For example, the Washington Post reported that by October 2003, hybrid vehicles accounted for roughly $25-30 \%$ of traffic in HOV-3 lanes, or roughly 1,700 cars per day. This is equivalent to approximately one-third of hybrid sales in Virginia from 2000 through third quarter 2003. ${ }^{13}$ We find that the HOV-3 rush hour lane restriction is associated with a statically significant reduction in this effect. Our point estimate for the effect of the HOV lane restriction falls to $41 \%$ following the HOV-3 restriction. While the point estimates for

incentives change the magnitude of the estimated coefficient, but do not change the significance or our conclusions.

${ }^{13}$ See “As Hybrid Cars Multiply, So Do Carpooling Gripes”, Steven Ginsberg and Carol Morello, Washington Post, Friday, January 7, 2005. 
New Jersey, Utah and California are negative and imprecisely estimated, it is interesting that the point estimate for the state with the most recent program, Florida, is negative and significant.

Like government incentives, we expect that changes in gasoline prices induce consumers to purchase more fuel-efficient vehicles. Furthermore, we expect that changes in gasoline price should have a greater effect on demand for high-economy hybrids, and the effect on high-economy vehicles should be especially pronounced for high travel intensity states.

In our base specification, we estimate that hybrid sales are positively correlated with tax-inclusive gasoline prices. The impact of gasoline prices, though, comes predominately through the purchase of high-economy hybrid vehicles. Separately estimating gasoline cross-price elasticity for high and low-economy vehicles in specification (5), we estimate that a 10 percent change in gasoline price leads to an 8.6 percent increase in per-capita sales of high-economy hybrid vehicles. Our point estimate for the cross price elasticity of low-economy hybrids is close to zero (0.027) and not statistically significant. Furthermore, when we include interactions of our gasoline variables with annual per capita VMT, we find that the relationship between gasoline prices and high-economy hybrid sales is significantly more pronounced in high VMT states, consistent with our prediction that high mileage individuals have the greatest incentive to adopt high-fuel economy hybrids in response to an increase in gasoline prices.

\section{Tax Salience}


States offer both income tax credits and sales tax exemptions as incentives for hybrid vehicle purchase. In addition to studying the generosity of the tax incentives, we test whether the form of the state tax incentive affects hybrid vehicle sales. Our ex-ante expectation is that, conditional on the value of the incentive, consumers may be more sensitive to sales tax incentives rather than income tax incentives. Sales tax incentives are automatically and directly incorporated into the cost of the vehicle at the time of purchases. Incentives granting a state income tax credit, on the other hand, must be known, understood, and applied for in the future by eligible purchasers. Income tax credits can only be claimed the following year, rather than at the time of purchase. Furthermore, the benefit of an income tax credit is also uncertain - to the extent that the value of the incentive exceeds a consumer's tax burden, they may be ineligible to claim the full value of the incentive.

Table 4 presents our results in which we separately estimate coefficients for the value of sales tax waivers and income tax credits. In specification (1), we find that that offering an income tax incentive is associated with a significantly larger increase in demand of hybrid vehicles than offering a comparably valuable income tax incentive. We estimate that the coefficient on value of sales tax incentives is 0.227 and the coefficient on the value of income tax incentives is 0.020 . When measured relative to vehicle MSRP, we again find that sales tax incentives are associated with a greater increase in hybrid vehicle sales than income tax credits. We estimate that a sales tax incentive equal to 5 percent of the retail price is associated with a 26 percent increase in sales - an income tax credit equivalent to 5 percent of the retail price is associated with a 7 percent increase in retail sales. 
We also estimate a specification using dummy variables corresponding to whether a particular state offers an income tax credit or a sales tax exemption. We estimate that demand for hybrid models eligible for a sales tax incentive are 28 percent greater than demand for hybrid models ineligible for state tax incentive. We estimate demand for models eligible for income tax incentives are 13 percent greater than those ineligible for state tax incentives. Moreover, estimates from the specification using dummy variables understate the true relative effect - state income tax incentives are twice as generous (Mean=\$2,011) on average than sales tax incentives (Mean=\$1,037).

To better understand why income tax credits create poorer incentives than sales tax waivers, we estimate quarterly coefficients for the value of income tax credits in specifications (4) and (5). While the incentive effect of a sales tax waiver should not vary intertemporally since it is obtained at the time of purchase, the incentives created by an income tax credit may plausibly vary intertemporally. Moreover, the pattern of intertemporal variation we would expect should vary depending on the source of the difference in incentives - thus, we could plausibly use the pattern of intertemporal variation to distinguish between different explanations. Specifically, if poorer incentives arise from the delay in collecting the tax credit, we would expect the effect of the tax credit to be monotonically increasing over the course of the tax year - the coefficient on the value of the tax credit should increase with each successive quarter, being smallest in the first quarter and greatest in the fourth quarter. If on the other hand, individuals receive imperfect information about the value of the incentive or are poorly informed of incentive value, we might expect that the effect of the incentive is greatest in the second quarter after taxes are filed and then declines in subsequent quarters. When we estimate 
quarterly coefficients using either the absolute or relative value of the incentive, we find an intertemporal pattern consistent with the second story - the point estimate of the coefficient is greatest in the second quarter and declines monotonically with each successive quarter.

Although we do not observe the transaction price associated with vehicle purchases and cannot observe how the consumers and dealers allocate the government incentive, we do not believe the omission of bargaining between consumers and dealers to substantively affect our results. Sallee (2007) finds evidence that consumers capture the vast majority of tax incentives targeted at the Prius. To the extent that dealer/consumer bargaining varies by type of incentive offered, we expect bargaining to conservatively bias the difference between the effect of a sales tax waiver and income tax credit. Busse, Silva-Risso and Zettlemeyer (2006) find that information asymmetries play an important role in the incidence of dealer and consumer vehicle incentives. In the context of tax incentives, we would expect that the value of a sales tax waivers would be clearly known to both parties at the time of negotiation, while the value of an income tax credit depends the consumer's tax position, which is private information. In addition, if a consumer's objective is to pay less than or equal to a particular price for a vehicle, the consumer might bargain less aggressively if they know they will receive the sales tax waiver. Both of these explanations would lead us to underestimate the coefficient on the value of the sales tax waiver by more than that coefficient on the income tax credit and, thus, understate, the true relative benefit of the tax incentives.

Social Preferences 
Conditional on purchasing a hybrid, we expect that groups with strong preferences for environmentalism or energy security to prefer high-economy hybrids, which have substantial environmental or energy security benefits, relative to loweconomy hybrids. We test a set of measures plausibly correlated with environmentalism, a measure of travel intensity and a set of measures plausibly correlated with preferences for enhanced energy security. As a metrics for environmentalism, we use state-level Sierra Club membership per capita. In addition, we use quarterly deviation from 100 year average temperatures as a metric for the local salience of global warming. We also include two metrics related to the wars in Iraq and Afghanistan, which are plausibly correlated with U.S. consumer preferences for enhanced energy security: per-capita active and reserve military participation, and per-capita home-state casualties in Iraq and Afghanistan.

We estimate equation (2) replacing the state*model fixed effects from equation (1) with a state dummy variable and interactions of our preference metrics with a dummy for high-economy vehicles. We cluster errors at the state-level to account for the fact that some of our preference metrics are time-invariant within state. In our results, we interpret the state fixed effect as a state's mean preference for hybrid vehicles and we can interpret the coefficients on the interaction terms as the correlation between our ideology metrics and preferences for high efficiency hybrids. In specification (1), we estimate a joint cross-price elasticity with respect to gasoline. In specification (2), we separately estimate the coefficient on the log of gasoline price for high and low-economy hybrid vehicles. We present our results in table 5 , omitting the presentation of the demographic variables for brevity. The interaction terms for Sierra Club Membership and Military 
Participation are positive and significant. The interaction terms for mean temperature deviation and was casualties are imprecisely estimated. Based on the estimates from specification (2), we estimate that a one standard deviation increase in Sierra Club membership per capita and per-capita military participation are associated with 15 percent and 12 percent increases in demand for hybrid vehicles.

Finally, we test for evidence that Prius and Insight purchases might be partially motivated by conspicuous consumption - the desire to appear "green" to other environmentalists by driving a noticeably hybrid vehicle. In specification (3) and (4), we include terms Prius and Insight interaction terms with per capita Sierra Club Membership. We interpret the coefficients on the interaction terms as model-specific preferences incremental to the underlying preference for high economy vehicles. We estimate a positive and significant coefficient for the Prius, suggesting that consumers in states with high Sierra Club Membership have a preference for the Prius incremental to their relative preference for high economy hybrid vehicles. Interestingly, we find that a negative and significant coefficient for the Insight, suggesting that states with high Sierra Club membership have a lower preference for the Insight than other hybrid vehicles.

Since the Prius and Insight are the most fuel efficient of hybrid vehicles, though, this does not necessarily provide evidence of conspicuous consumption - consumers in states with high Sierra Club Membership likely have an especially strong preference for fuel economy as a way to reduce energy usage. If this explanation were true, we could expect to see two other predictions in the data. First, we would expect to see a similar relationship for states with high military participation - if consumers in these states also placed an especially high preference for fuel economy as a way to reduce energy use. In 
addition, we might expect our result to disappear if we replaced the terms interacting the high economy dummy variable and the proxies for environmentalism or energy security preference with terms interacting a vehicle's fuel economy with our proxies. We present these results in specifications (5) and (6). In all cases, the Prius-specific preference in states with high Sierra Club Membership per capita remains positive and significant. When we include the terms interacting a vehicle's fuel economy with our proxies, the point estimate rises rather than falls. ${ }^{14}$ These results suggest that consumers in states with high Sierra Club membership place an especially high preference on Prius incremental to that due to the Prius' high fuel economy, consistent with a desire by consumers to purchase an observably "green" vehicle.

\section{Sensitivity Tests}

Table 6 presents a number of sensitivity tests to our base econometric specification. In our first sensitivity test, we estimate our base econometric specification allowing for errors to be AR(1). In sensitivity test two, we include a third set of fixed effects, state*quarter FE, to control for seasonality in gasoline prices which may be correlated with seasonality in vehicle sales. In our third sensitivity test, we restrict our analysis to observations with above median quarterly model-level sale. In our fourth sensitivity test, we omit quarters in which we document production constraints for the Civic Hybrid and Toyota Prius. Finally, we run a sensitivity test exclusing the three lowest volume models, the Honda Insight, Saturn VUE and Lexus GS450h, which all sell less than 5,000 units over our sample period.

\footnotetext{
${ }^{14}$ We omit regressions in which we use higher-order fuel economy terms - our conclusions are robust to the parameterization of the fuel economy interaction term.
} 
Our point estimates and conclusions for the demographic variables are unchanged by the five sensitivity tests. The coefficient on retail gasoline prices is positive and significant at or below the $10 \%$ level for all five specifications. Point estimates vary from 0.583 to 0.804 . The coefficient on the value of state tax incentives is positive for all five of the sensitivity tests, but significant in only two of the five. Finally the coefficient on HOV access is negative for all five of the sensitivity tests and imprecisely estimated in all but one.

\section{Policy Implications and Conclusions}

Our empirical results have several important implications for the design of consumer hybrid incentives as well as for the design of more general incentives meant to foster consumer adoption of energy-efficient technology. We find evidence that the type of tax incentive offered affects consumer behavior, even when taking the generosity of the tax incentive into account. Consumer response is greater to a sales tax exemption, which is immediate and automatic at the time of purchase, than to an income tax credit, for which a consumer must understand, apply for, and eventually collect as part of their tax return. Even though sales tax incentives tend to be less generous than income tax credits, we find that the mean sales tax waiver (value \$1,077) increases demand to a greater degree than the mean income tax credit (value \$2,011). This suggests that the immediacy and ease of tax benefit is a central attribute of any tax incentive meant to speed consumer adoption of energy efficient goods.

The tax salience result also suggests that "feebate" programs, where consumers pay (or are given, in the case of high fuel economy vehicles) a fee at the time of purchase 
based on vehicle fuel economy, would be likely be effective at encouraging consumers to purchase more efficient vehicles. The immediacy of a feebate may induce behavior in a similar way to sales tax waivers and could plausibly be more effective at inducing consumer purchase of high economy vehicles than emission or fuel economy based registration or emissions testing fees. Moreover, a feebate could plausibly be designed to be revenue neutral, unlike sales tax waivers.

With respect to single-occupancy HOV access, we find weaker evidence of consumer response. Only the HOV program offered by Virginia is estimated to have a statistically significant effect. In the case of Virginia, though, we find the estimated effect to be quite large, and find that the programs' effect on demand falls after the Virginia placed restrictions on hybrid vehicle access to HOV-3 lanes during rush hour.

A second interesting comparison follows from comparing the effect of a mean sales tax incentive and the estimated effect of rising gasoline prices. We estimate that a mean sales tax incentive of $\$ 1,077$ is associated with an equivalent increase in demand for high-economy hybrid vehicles as a 26 percent increase in gasoline prices. We estimate the incremental annual gasoline savings for an individual choosing to purchase a hybrid vehicle at $\$ 132$ per year, equivalent to roughly a 13 percent discount rate on gasoline prices. ${ }^{15}$ Although this is an almost certainly conservative estimate of the discount rate, the result is notable in that it is substantially less than estimates in much of the previous literature (e.g. Hausman and Joskow (1982)), which have suggested that consumers place a very high discount rate on future energy costs. Although a rough

\footnotetext{
${ }^{15}$ Incremental gasoline savings assumes a starting gasoline price equal to the mean during the sample period (\$1.80 per gallon), an individual driving 15,000 miles per year and replacing a car of 2004 average fleet fuel economy (24.6 mpg) with a 2005 Toyota Prius (46 mpg).
} 
approximation, this suggests that at least a subset of early adopters use a low discount rate when incorporating future energy costs into current decisions.

The relative effect of tax incentives and rising gasoline prices can additionally be seen by comparing predictions of high-economy hybrid sales absent tax incentives and/or rising gasoline prices. Using our estimates from our empirical model, we estimate the contribution of government incentives, gasoline prices and social preferences to actual high-economy hybrid sales over 2000-2006. To measure the contribution of each, we predict hybrid vehicle demand under three alternative scenarios. First, we estimate demand absent state or federal government incentives. Second, we estimate demand holding setting gasoline prices over the entire period equal \$1.44 per gallon, the mean gasoline price from January, 2000 through December, 2003. Last, we estimate demand setting our proxies for social preferences equal to zero.

Figure 2 graphs actual and predicted sales of high-economy hybrids under each of the three scenarios. The solid black and red lines represent the actual and predicted higheconomy sales from our base empirical model. The three dashed lines represent predicted sales from each of our three scenarios and the solid blue line represents the predicted sales from the intersection of the three adjustments. We find that the higher gasoline prices and our metrics for preferences for energy security or environmentalism are associated with substantially greater hybrid vehicle adoption that state and federal tax incentives - we estimate that gasoline prices and consumer preferences are associated with 27 percent and 36 percent of high-economy hybrid sales over this period, while government tax incentives are associated with only 6 percent of high-economy hybrid sales. These estimates are likely conservative, since they do not incorporate the dynamic 
effects of early adoption on later adoption. Furthermore, at best our metrics for social preferences capture part but not all of the true effect.

Our work suggests several important implications for policy intended to stimulate accelerated consumer purchase of hybrid-vehicle technology. First, tax incentive design plays an important role in regulatory efficacy - we find that sales tax incentives which are immediate and easy to obtain have a much greater effect on the demand for hybrid vehicles than income tax incentives which are delayed and likely more difficult to apply for and obtain. Second, we find that while single-occupancy HOV access is correlated with substantial hybrid adoption in Virginia, this is only true in Virginia, perhaps due to the small number of other states offering this incentive or because traffic congestion is more severe in Virginia than in other states with this program. Finally, an interesting conclusion of our work is that even though state and federal incentives are significant in many cases, much of the recent increase in hybrid vehicles sales is more likely to be the result of rising gasoline prices or social preferences than existing forms of government incentives. This suggests that government policies which increase the price of gasoline may stimulate greater consumer adoption of hybrid technology. Although the U.S. government has not used higher gasoline taxes as a policy instrument to motivate consumer adoption of more fuel-efficient vehicles, this is a policy tool that has been employed to varying degrees in Europe and Japan. 


\section{References}

Bento, A., Goulder, L., Jacobsen, M., and R. vonHaefen (2006), "Distributional and Efficiency Impacts of Increased US Gasoline Taxes.” NBER Working Paper.

Busse, M., Silva-Risso, J., and F. Zettlemeyer (2006), “\$1000 Cash Back: Pass-through of Auto Manufacturer Promotions,” American Economic Review, 96: 1253-1270.

Chetty, R., Looney, A., and K. Kroft (2007), "Salience and Taxation: Theory and Evidence,” Working Paper.

Energy Information Administration (2007), “Tax Rates on Motor Fuel,” U.S. Department of Energy, Washington, DC: February.

Finkelstein, Amy (2007), “E-Z Tax: Tax Salience and Tax Rates,” Working Paper.

Geroski, P.A. (2000), “Models of Technology Diffusion,” Research Policy 29: 603-625.

Greene, D., Patterson, P., Singh, M., and J. Li (2005), “Feebates, rebates and gas-guzzler taxes: a study of incentives for increased fuel economy,” Energy Policy, 33: 757-775.

Grubler, A. (1998), Technology and Global Change, Cambridge: Cambridge University Press.

Hausman, J., and P. Joskow (1982), "Evaluating the Costs and Benefits of Appliance Efficiency Standards,” American Economic Review, 72: 220-225.

Hughes, J., Knittel, C., and Sperling, D. (2008), "Evidence of a Shift in the Short-Run Price Elasticity of Gasoline Demand" The Energy Journal, forthcoming.

Jaffe, A., Newell, R. and R. Stavins, “The Induced Innovation Hypothesis and EnergySaving Technological Change,” Quarterly Journal of Economics, 117: 941-975.

JD Power \& Associates Power Information Network (2007), "Market Share and Sales Volume for Midsize Non-Premium SUVs Plummet,” Press Release, June.

Kahn, M. (2007), "Do Greens Drive Hummers Or Hybrids? Environmental Ideology as a Determinant of Consumer Choice and the Aggregate Ecological Footprint", Working Paper.

Kahn, M. (2007), “Who Are Early Adopters of New Energy Efficient Products: Evidence from Hybrid Vehicle Registrations,” Working Paper.

Klier, T., and J. Linn (2007), "Gasoline Prices and the Demand for New Vehicles: Evidence from Monthly Sales Data,” Working Paper. 
McDonald, A. and L. Schrattenholzer (2002), "Learning Curves and Technology Assessment,” International Journal of Technology Management, 23 (7/8).

McManus, W. (2006), “Can Proactive Fuel Economy Strategies Help Automakers Mitigate Risks?” University of Michigan Transportation Research Institute, Discussion Paper.

National Research Council (NRC) (2002), "Effectiveness and Impact of Corporate Average Fuel Economy Standards,” National Academies Press, Washington, DC.

Rogers, E.M. (1995), Diffusion of Innovations, New York: Free Press.

Schäfer A., and H.D. Jacoby (2006), Vehicle Technology Dynamics under $\mathrm{CO}_{2}$ Constraint: A General Equilibrium Analysis, Energy Policy, 34 (9): 975-985.

Sallee, J. (2007), “Tax Credits and the Market for Hybrid Vehicles”, working paper.

Turrentine, T. and K. Kurani (2007), “Car Buyers and Fuel Economy,” Energy Policy, 35, 1213-1223.

West, S. (2007), “The Effect of Gasoline Prices and the Demand for Sport Utility Vehicles,” Working Paper. 
Figure 1 - Domestic Hybrid Sales

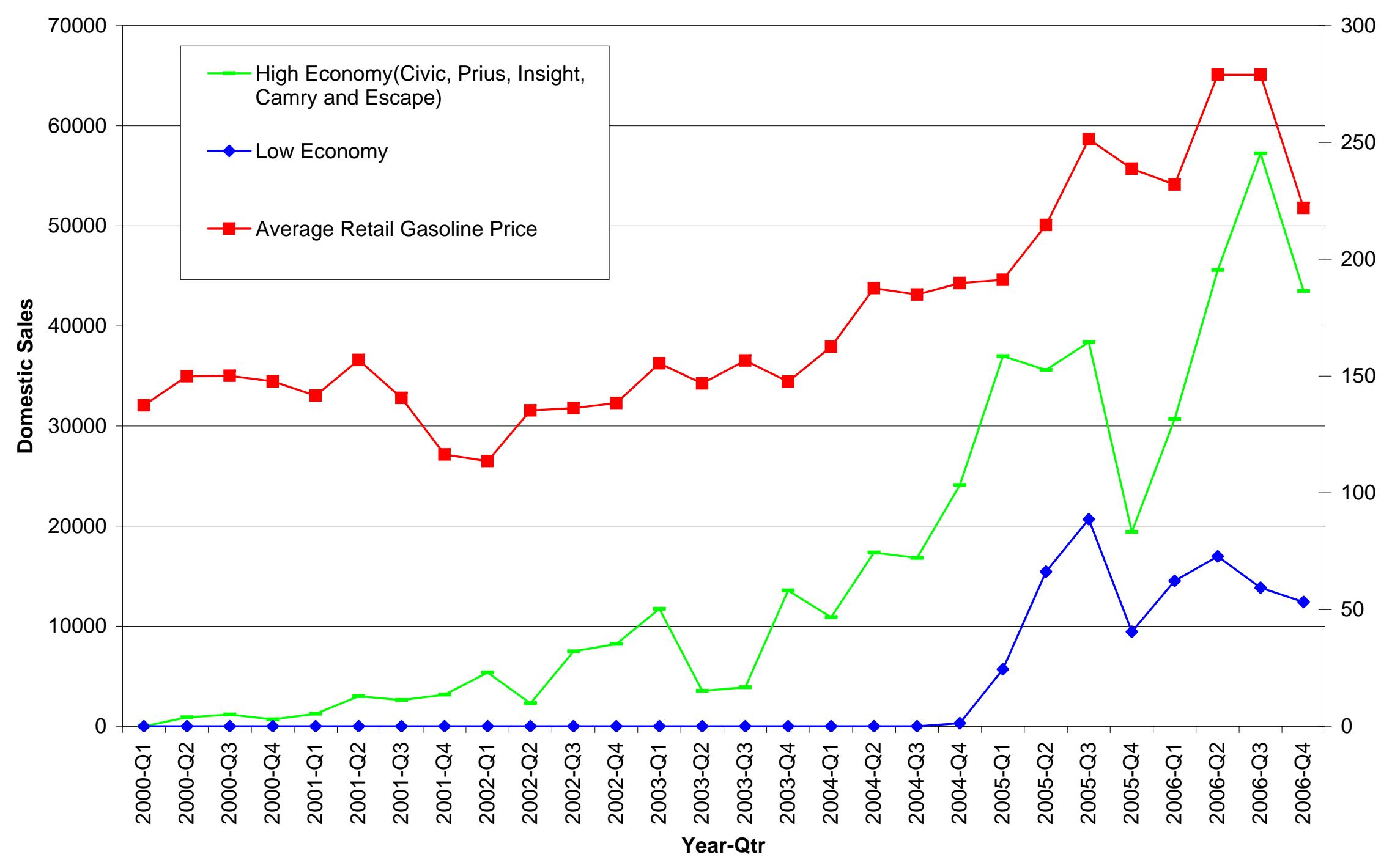




\section{Figure 2: Actual and Predicted High Economy Hybrid Sales}

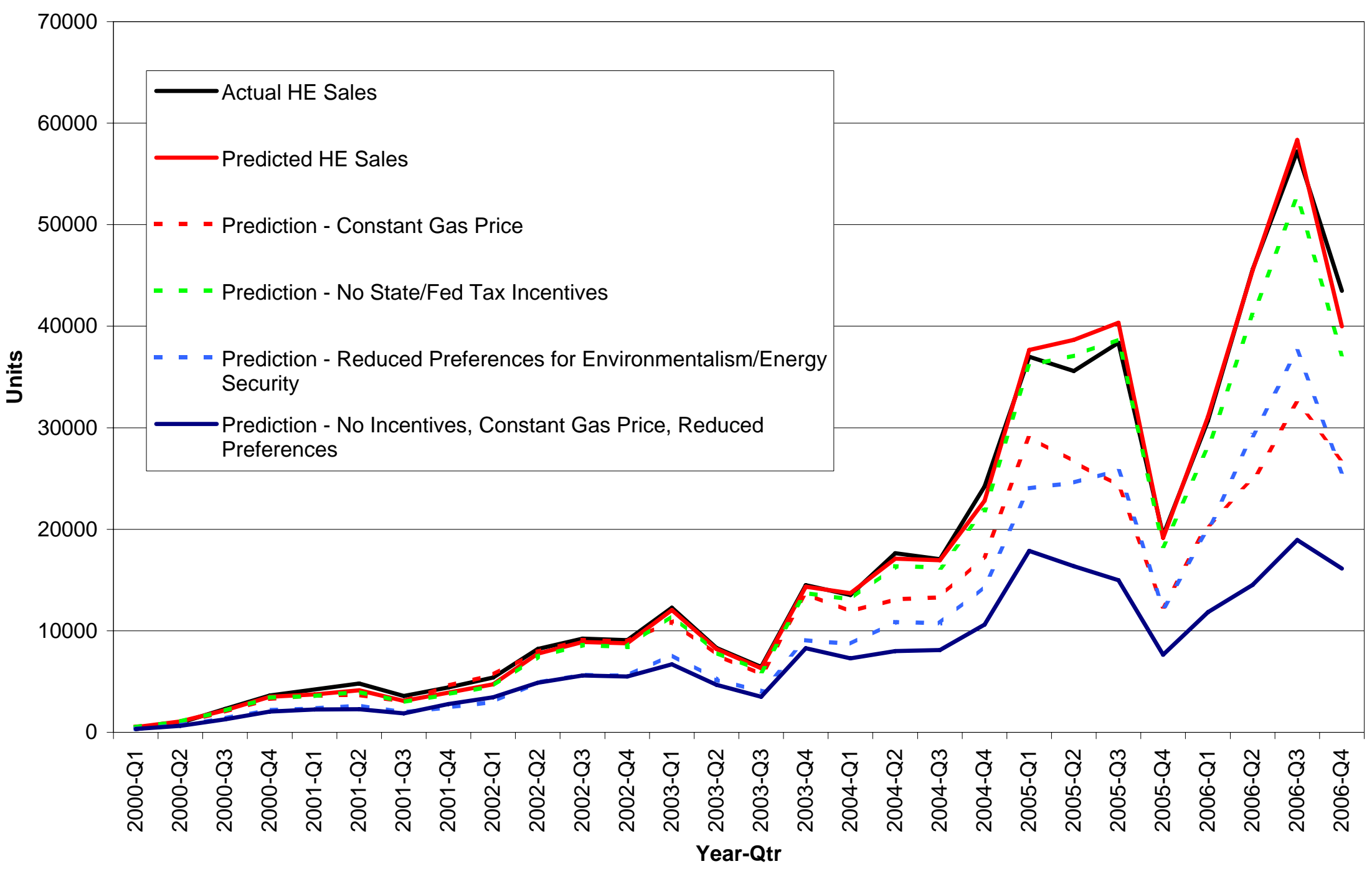




\begin{tabular}{|c|c|c|c|c|c|c|}
\hline \multicolumn{7}{|c|}{ Table 1. State Incentives and Policies for Hybrid Electric Vehicles } \\
\hline HOV Lanes & Income Tax Credit & $\begin{array}{c}\text { Sales Tax } \\
\text { Exemption }\end{array}$ & $\begin{array}{c}\text { Vehicle Emissions } \\
\text { Test Exemption }\end{array}$ & $\begin{array}{c}\text { State Gov. Purchasing } \\
\text { Requirement }\end{array}$ & $\begin{array}{c}\text { Registration or } \\
\text { Excise Tax } \\
\text { Exemption or Rebate }\end{array}$ & $\begin{array}{l}\text { Parking Fee Reduction or } \\
\text { Exemptions (cities) }\end{array}$ \\
\hline AZ (pilot) & $\mathrm{CO}$ & CT (HE) & $\mathrm{CO}(\mathrm{HE})$ & MN & DC & Albuquerque, NM \\
\hline $\mathrm{CA}(\mathrm{HE})$ & $M D^{*}$ & DC & MD & NM & IL (HE) & Austin, TX \\
\hline CO (on hold) & $\mathrm{NY}(\mathrm{HE})^{\star}$ & $\mathrm{ME}^{\star}$ & WA & NY & NM & Baltimore, MD \\
\hline FL & OR & NM (HE) & & WI & PA & Ferndale, MI \\
\hline GA (on hold) & S. CA & $N Y(H E)^{*}$ & & & & Huntington, NY \\
\hline $\mathrm{NJ}$ & UT & WA (2009-2011) & & & & Los Angeles, CA \\
\hline NY (pilot) & W. VA* & & & & & New Haven, CT \\
\hline UT & PA & & & & & Salt Lake City, UT \\
\hline \multirow[t]{5}{*}{ VA } & & & & & & San Antonio, TX \\
\hline & & & & & & San Jose, CA \\
\hline & & & & & & Santa Monica, CA \\
\hline & & & & & & Vail, CO \\
\hline & & & & & & Westchester, NY \\
\hline
\end{tabular}


Table 2: Summary Statistics*

\begin{tabular}{|c|c|c|c|c|c|}
\hline Variable & $\mathrm{N}$ & Mean & Std. Dev & Min & $\operatorname{Max}$ \\
\hline \multicolumn{6}{|l|}{ Sales Data } \\
\hline Vehicle Sales & 4781 & 121.1 & 386.0 & 1.0 & 8871.0 \\
\hline Vehicle Sales Per Thousand Pop & 4781 & 0.017 & 0.025 & 0.000 & 0.243 \\
\hline \multicolumn{6}{|l|}{ Hybrid Vehicle Incentive Data } \\
\hline HOV_lane access & 4781 & 0.055 & 0.228 & 0.0 & 1.0 \\
\hline Federal Tax Incentive & 4300 & 1073.26 & 797.10 & 560.0 & 3150.0 \\
\hline State Income Tax Credit & 465 & 2011.36 & 1025.71 & 130.0 & 4713.0 \\
\hline State Sales Tax Incentive & 173 & 1037.16 & 640.05 & 300.0 & 2721.6 \\
\hline Total Tax Incentive & 4331 & 1270.42 & 1014.77 & 300.0 & 6435.0 \\
\hline \multicolumn{6}{|l|}{ State Level Data } \\
\hline Per Capita Income & 1228 & 32.13 & 5.68 & 21.01 & 56.33 \\
\hline Percent of Adults Graduating High School & 1228 & 0.86 & 0.04 & 0.77 & 0.93 \\
\hline Percent of Adults Graduating College & 1228 & 0.27 & 0.06 & 0.15 & 0.49 \\
\hline Percent Female & 1228 & 0.51 & 0.01 & 0.48 & 0.53 \\
\hline Mean Age & 1228 & 36.46 & 1.45 & 30.64 & 39.55 \\
\hline Sierra Club Members & 1228 & 13916.63 & 23221.92 & 535.00 & 153619.00 \\
\hline Sierra Club Membership, Per Thousand Pop & 1228 & 2.18 & 1.25 & 0.38 & 5.37 \\
\hline Retail Gasoline Price, Tax Inclusive & 1228 & 180.13 & 47.26 & 99.43 & 310.27 \\
\hline War Casualties & 1228 & 2.57 & 4.42 & 0.00 & 41.00 \\
\hline War Casualties, Per Thousand Pop & 1228 & 0.0005 & 0.0007 & 0.0000 & 0.0079 \\
\hline Vehicle Miles Traveled, Per Capita (000) & 1172 & 10.43 & 1.94 & 6.79 & 18.34 \\
\hline Armed Forced Participation, Per Capita & 1228 & 0.0094 & 0.0074 & 0.0025 & 0.0383 \\
\hline
\end{tabular}

* For tax incentive and vehicle sales variables, $\mathrm{N}$ is the number of observations with non-zero observations.

As a result, the summary statistics for tax incentives are conditonal on an incentive being offered

and the summary statistics for vehicle sales are conditional on positive sales. 
Table 3: Effects of Hybrid Incentives

Dependent Variable: Log Per Capita Sales

\begin{tabular}{|c|c|c|c|c|c|c|c|}
\hline \multirow[t]{2}{*}{ Variable } & \multicolumn{7}{|c|}{ Specification } \\
\hline & $(1)$ & $(2)$ & $(3)$ & $(4)$ & $(5)$ & $(6)$ & $(7)$ \\
\hline \multirow[t]{2}{*}{ log Per Capita Income } & 1.634 & 2.112 & 2.113 & 2.093 & 2.109 & 2.112 & 2.049 \\
\hline & $(0.424)^{\star \star}$ & $(0.457)^{\star \star}$ & $(0.457)^{\star \star}$ & $(0.456)^{\star \star}$ & $(0.459)^{\star \star}$ & $(0.456)^{\star \star}$ & $(0.495)^{\star \star}$ \\
\hline \multirow[t]{2}{*}{ log Mean Age } & -21.612 & -15.401 & -15.406 & -15.013 & -15.617 & -15.203 & -14.966 \\
\hline & $(3.078)^{\star \star}$ & $(3.437)^{\star \star}$ & $(3.437)^{\star \star}$ & $(3.441)^{\star \star}$ & $(3.449)^{\star \star}$ & $(3.464)^{\star \star}$ & $(3.674)^{\star \star}$ \\
\hline \multirow[t]{2}{*}{ Log Percent Female } & 5.904 & -1.081 & -1.085 & -0.185 & -1.574 & -1.179 & 2.158 \\
\hline & (11.203) & $(12.930)$ & $(12.915)$ & $(12.850)$ & $(12.984)$ & $(12.937)$ & $(13.492)$ \\
\hline \multirow[t]{2}{*}{ log Percent HS Graduate } & 0.879 & 1.064 & 1.066 & 1.015 & 1.034 & 1.074 & 1.193 \\
\hline & $(0.742)$ & $(0.793)$ & $(0.792)$ & $(0.792)$ & $(0.791)$ & $(0.792)$ & $(0.797)$ \\
\hline \multirow[t]{2}{*}{ log Percent College Grad } & -0.126 & -0.157 & -0.155 & -0.153 & -0.150 & -0.155 & -0.187 \\
\hline & $(0.184)$ & $(0.197)$ & $(0.197)$ & $(0.196)$ & $(0.198)$ & $(0.197)$ & $(0.196)$ \\
\hline \multirow[t]{2}{*}{ State Tax Incentive $(\$ 000)$} & 0.031 & 0.049 & & & 0.049 & 0.049 & 0.054 \\
\hline & $(0.021)$ & $(0.026)+$ & & & $(0.026)+$ & $(0.026)+$ & $(0.027)^{\star}$ \\
\hline \multirow[t]{2}{*}{ State Tax Incentive/MSRP } & & & 1.064 & & & & \\
\hline & & & $(0.558)+$ & & & & \\
\hline \multirow[t]{2}{*}{ State Tax Incentive Dummy } & & & & 0.172 & & & \\
\hline & & & & $(0.047)^{\star \star}$ & & & \\
\hline \multirow[t]{2}{*}{ HOV access dummy } & 0.024 & -0.082 & -0.082 & -0.077 & & -0.079 & -0.075 \\
\hline & $(0.071)$ & $(0.059)$ & $(0.059)$ & $(0.058)$ & & $(0.059)$ & $(0.059)$ \\
\hline \multirow[t]{2}{*}{ UT HOV Access } & & & & & -0.117 & & \\
\hline & & & & & $(0.264)$ & & \\
\hline \multirow[t]{2}{*}{ CA HOV Access } & & & & & -0.096 & & \\
\hline & & & & & $(0.096)$ & & \\
\hline \multirow[t]{2}{*}{ VA HOV Access } & & & & & 0.657 & & \\
\hline & & & & & $(0.170)^{\star \star}$ & & \\
\hline \multirow[t]{2}{*}{ VA HOV Access * post 7/1/06 } & & & & & -0.246 & & \\
\hline & & & & & $(0.062)^{\star \star}$ & & \\
\hline \multirow[t]{2}{*}{ FL HOV Access } & & & & & -0.161 & & \\
\hline & & & & & $(0.075)^{\star}$ & & \\
\hline \multirow[t]{2}{*}{ NJ HOV Access } & & & & & -0.011 & & \\
\hline & & & & & $(0.093)$ & & \\
\hline \multirow[t]{2}{*}{ log Retail Gasoline Price } & 1.092 & 0.712 & 0.712 & 0.751 & 0.677 & & \\
\hline & $(0.318)^{\star \star}$ & $(0.308)^{\star}$ & $(0.308)^{\star}$ & $(0.310)^{\star}$ & $(0.313)^{\star}$ & & \\
\hline \multirow[t]{2}{*}{ log Retail Gas Price * Low Economy } & & & & & & 0.027 & -0.278 \\
\hline & & & & & & $(0.935)$ & $(1.038)$ \\
\hline \multirow[t]{2}{*}{ log Retail Gas Price * High Economy } & & & & & & 0.862 & 0.675 \\
\hline & & & & & & $(0.307)^{\star \star}$ & $(0.318)^{\star}$ \\
\hline \multirow[t]{2}{*}{ log Retail Gas Price * LE * PerCapVMT } & & & & & & & 0.006 \\
\hline & & & & & & & $(0.028)$ \\
\hline log Retail Gas Price * HE * PerCapVMT & & & & & & & 0.014 \\
\hline & & & & & & & $(0.006)^{\star}$ \\
\hline Constant & 65.296 & 38.361 & 38.378 & 37.404 & 39.097 & 38.439 & 40.423 \\
\hline & $(14.994)^{\star *}$ & $(15.706)^{\star}$ & $(15.704)^{\star}$ & $(15.729)^{*}$ & $(15.810)^{\star}$ & $(15.720)^{*}$ & $(16.675)^{\star}$ \\
\hline State FE & $\mathrm{x}$ & & & & & & \\
\hline State*Model FE & & $x$ & $x$ & $x$ & $x$ & $x$ & $x$ \\
\hline Time*Model FE & $\mathrm{x}$ & $\mathrm{x}$ & $\mathrm{x}$ & $\mathrm{x}$ & $\mathrm{x}$ & $\mathrm{x}$ & $\mathrm{x}$ \\
\hline Observations & 4781 & 4781 & 4781 & 4781 & 4781 & 4781 & 4630 \\
\hline R-squared & 0.50 & 0.51 & 0.68 & 0.68 & 0.68 & 0.68 & 0.68 \\
\hline
\end{tabular}

Standard errors in parentheses, clustered by state and time.

+ significant at 10\%; * significant at $5 \%$; ** significant at $1 \%$ 
Table 4: Tax Salience

Dependent Variable: Log Per Capita Sales

\begin{tabular}{|c|c|c|c|c|c|}
\hline \multirow{2}{*}{ Variables* $^{*}$} & \multicolumn{5}{|c|}{ Specification } \\
\hline & (1) & $(2)$ & (3) & (4) & (5) \\
\hline log Retail Gasoline Price & $\begin{array}{c}0.735 \\
(0308)^{*}\end{array}$ & $\begin{array}{c}0.738 \\
(0308)^{*}\end{array}$ & $\begin{array}{c}0.757 \\
(0.310) *\end{array}$ & $\begin{array}{c}0.729 \\
(0.308)^{*}\end{array}$ & $\begin{array}{c}0.741 \\
(0.308) *\end{array}$ \\
\hline HOV access dummy & $\begin{array}{l}-0.077 \\
(0.058)\end{array}$ & $\begin{array}{l}-0.077 \\
(0.058)\end{array}$ & $\begin{array}{l}-0.076 \\
(0.058)\end{array}$ & $\begin{array}{c}-0.076 \\
(0.058)\end{array}$ & $\begin{array}{l}-0.077 \\
(0.058)\end{array}$ \\
\hline State Tax Credit $(\$ 000)$ & $\begin{array}{c}0.027 \\
(0.026)\end{array}$ & & & & \\
\hline State Sales Tax Incentive $(\$ 000)$ & $\begin{array}{c}0.227 \\
(0.106)^{\star}\end{array}$ & & & $\begin{array}{l}0.227 \\
(0.106)^{\star}\end{array}$ & \\
\hline State Income Tax Credit/MSRP & & $\begin{array}{c}0.571 \\
(0.551)\end{array}$ & & & \\
\hline State Sales Tax Incentive/MSRP & & $\begin{array}{c}5.134 \\
(2.356)^{\star}\end{array}$ & & & $\begin{array}{l}5.137 \\
(2.356)^{\star}\end{array}$ \\
\hline State Tax Credit Dummy & & & $\begin{array}{c}0.131 \\
(0.048)^{\star \star}\end{array}$ & & \\
\hline State Sales Tax Dummy & & & $\begin{array}{c}0.282 \\
(0.119)^{\star}\end{array}$ & & \\
\hline State Tax Credit $(\$ 000)^{\star} \mathrm{Qtr}=1$ & & & & $\begin{array}{l}0.013 \\
(0.033)\end{array}$ & \\
\hline State Tax Credit $(\$ 000)^{\star} \mathrm{Qtr}=2$ & & & & $\begin{array}{l}0.037 \\
(0.029)\end{array}$ & \\
\hline State Tax Credit $(\$ 000)^{\star} \mathrm{Qtr}=3$ & & & & $\begin{array}{l}0.032 \\
(0.031)\end{array}$ & \\
\hline State Tax Credit $(\$ 000)^{\star} \mathrm{Qtr}=4$ & & & & $\begin{array}{l}0.028 \\
(0.034)\end{array}$ & \\
\hline (State Tax Credit/MSRP)*Qtr=1 & & & & & $\begin{array}{l}0.319 \\
(0.718)\end{array}$ \\
\hline$\left(\right.$ State Tax Credit/MSRP) ${ }^{\star} \mathrm{Qtr}=2$ & & & & & $\begin{array}{l}0.886 \\
(0.589)\end{array}$ \\
\hline$\left(\right.$ State Tax Credit/MSRP) ${ }^{\star} \mathrm{Qtr}=3$ & & & & & $\begin{array}{l}0.639 \\
(0.694)\end{array}$ \\
\hline$\left(\right.$ State Tax Credit/MSRP) ${ }^{\star} \mathrm{Qtr}=4$ & & & & & $\begin{array}{l}0.409 \\
(0.759) \\
\end{array}$ \\
\hline State*Model FE & $\mathrm{x}$ & $\mathrm{x}$ & $\mathrm{x}$ & $\mathrm{x}$ & $\mathrm{x}$ \\
\hline Time*Model FE & $\mathrm{x}$ & $\mathrm{x}$ & $\mathrm{x}$ & $\mathrm{x}$ & $\mathrm{x}$ \\
\hline Observations & 4781 & 4781 & 4781 & 4781 & 4781 \\
\hline R-squared & 0.68 & 0.68 & 0.68 & 0.68 & 0.68 \\
\hline
\end{tabular}

*Note: All models include Constant term and full set of Income, Age, Gender and Educational Controls.

Standard errors in parentheses, clustered by state and time.

+ significant at 10\%; * significant at 5\%; ** significant at $1 \%$ 
Table 5: Determinants of Demand for High Efficiency Hybrids Dependent Variable: Log Per Capita Sales

\begin{tabular}{|c|c|c|c|c|c|c|}
\hline \multirow{2}{*}{ Variables* $^{*}$} & \multicolumn{6}{|c|}{ Specification } \\
\hline & $(1)$ & $(2)$ & (3) & $(4)$ & (5) & (6) \\
\hline State Tax Incentive $(\$ 000)$ & $\begin{array}{c}0.039 \\
(0.039)\end{array}$ & $\begin{array}{c}0.037 \\
(0.039)\end{array}$ & $\begin{array}{c}0.041 \\
(0.034)\end{array}$ & $\begin{array}{c}0.040 \\
(0.034)\end{array}$ & $\begin{array}{c}0.039 \\
(0.032)\end{array}$ & $\begin{array}{c}0.038 \\
(0.033)\end{array}$ \\
\hline HOV lane access & $\begin{array}{l}-0.012 \\
(0.077)\end{array}$ & $\begin{array}{l}-0.016 \\
(0.078)\end{array}$ & $\begin{array}{l}-0.014 \\
(0.079)\end{array}$ & $\begin{array}{l}-0.019 \\
(0.080)\end{array}$ & & \\
\hline log Retail Gasoline Price & $\begin{array}{c}0.971 \\
(0.362)^{\star}\end{array}$ & & $\begin{array}{c}0.917 \\
(0.374)^{*}\end{array}$ & & $\begin{array}{c}1.011 \\
(0.380)^{\star}\end{array}$ & \\
\hline log Retail Gas Price * Low Economy & & $\begin{array}{c}0.092 \\
(0.663)\end{array}$ & & $\begin{array}{c}0.033 \\
(0.663)\end{array}$ & & $\begin{array}{c}-0.884 \\
(0.654)\end{array}$ \\
\hline log Retail Gas Price * High Economy & & $\begin{array}{c}1.111 \\
(0.389)^{\star \star}\end{array}$ & & $\begin{array}{c}1.062 \\
(0.404)^{\star}\end{array}$ & & $\begin{array}{c}1.307 \\
(0.410)^{\star \star}\end{array}$ \\
\hline Sierra Club Membership Per Capita * HE & $\begin{array}{c}0.134 \\
(0.027)^{\star \star}\end{array}$ & $\begin{array}{c}0.117 \\
(0.028)^{\star \star}\end{array}$ & $\begin{array}{c}0.129 \\
(0.028)^{\star \star}\end{array}$ & $\begin{array}{c}0.111 \\
(0.031)^{\star \star}\end{array}$ & & \\
\hline Military Participation Per Capita* HE & $\begin{array}{c}16.772 \\
(6.736)^{\star}\end{array}$ & $\begin{array}{c}17.384 \\
(6.851)^{\star}\end{array}$ & $\begin{array}{c}20.799 \\
(9.561)^{\star}\end{array}$ & $\begin{array}{c}21.281 \\
(9.750)^{\star}\end{array}$ & & \\
\hline Deviation from Mean Temp * HE & $\begin{array}{c}0.004 \\
(0.017)\end{array}$ & $\begin{array}{c}0.001 \\
(0.017)\end{array}$ & $\begin{array}{c}0.004 \\
(0.017)\end{array}$ & $\begin{array}{c}0.001 \\
(0.017)\end{array}$ & & \\
\hline War Casualties Per Capita * HE & $\begin{array}{c}-8.753 \\
(10.550)\end{array}$ & $\begin{array}{c}-9.578 \\
(10.282)\end{array}$ & $\begin{array}{c}-9.387 \\
(10.407)\end{array}$ & $\begin{array}{c}-10.207 \\
(10.131)\end{array}$ & & \\
\hline Sierra Club Memb Per Cap * Fuel Economy & & & & & $\begin{array}{c}0.004 \\
(0.002)^{\star}\end{array}$ & $\begin{array}{c}0.002 \\
(0.002)\end{array}$ \\
\hline Military Participation Per Cap * Fuel Economy & & & & & $\begin{array}{c}1.505 \\
(0.727)^{\star}\end{array}$ & $\begin{array}{c}1.589 \\
(0.743)^{\star}\end{array}$ \\
\hline Deviation from Mean Temp * Fuel Economy & & & & & $\begin{array}{c}0.000 \\
(0.000)\end{array}$ & $\begin{array}{l}-0.000 \\
(0.000)\end{array}$ \\
\hline War Casualties Per Capita * Fuel Economy & & & & & $\begin{array}{l}-0.129 \\
(0.252)\end{array}$ & $\begin{array}{l}-0.130 \\
(0.251)\end{array}$ \\
\hline Sierra Club Per Capita*Prius & & & $\begin{array}{c}0.092 \\
(0.018)^{\star \star}\end{array}$ & $\begin{array}{c}0.092 \\
(0.018)^{\star \star}\end{array}$ & $\begin{array}{c}0.102 \\
(0.023)^{\star \star}\end{array}$ & $\begin{array}{c}0.109 \\
(0.023)^{\star \star}\end{array}$ \\
\hline Sierra Club Per Capita*Insight & & & $\begin{array}{c}-0.089 \\
(0.035)^{\star}\end{array}$ & $\begin{array}{c}-0.089 \\
(0.034)^{\star}\end{array}$ & $\begin{array}{c}-0.091 \\
(0.043)^{\star}\end{array}$ & $\begin{array}{c}-0.078 \\
(0.043)+\end{array}$ \\
\hline Military Participation*Prius & & & $\begin{array}{l}-6.235 \\
(5.484)\end{array}$ & $\begin{array}{l}-6.035 \\
(5.463)\end{array}$ & $\begin{array}{l}-16.141 \\
(9.095)+\end{array}$ & $\begin{array}{l}-16.407 \\
(9.024)+\end{array}$ \\
\hline Military Participation*Insight & & & $\begin{array}{c}-6.810 \\
(20.711)\end{array}$ & $\begin{array}{c}-6.486 \\
(20.742)\end{array}$ & $\begin{array}{l}-21.124 \\
(26.253)\end{array}$ & $\begin{array}{l}-21.336 \\
(26.459)\end{array}$ \\
\hline Constant & $\begin{array}{c}50.339 \\
(29.873)+ \\
\end{array}$ & $\begin{array}{c}49.927 \\
(29.041)+ \\
\end{array}$ & $\begin{array}{c}52.435 \\
(29.667)+ \\
\end{array}$ & $\begin{array}{c}52.180 \\
(28.919)+ \\
\end{array}$ & $\begin{array}{l}58.628 \\
(29.881)+ \\
\end{array}$ & $\begin{array}{l}58.499 \\
(28.471)^{\star} \\
\end{array}$ \\
\hline State FE & $\mathrm{x}$ & $\mathrm{x}$ & $\mathrm{x}$ & $x$ & $x$ & $x$ \\
\hline Time*Model FE & $\mathrm{x}$ & $\mathrm{x}$ & $\mathrm{x}$ & $\mathrm{x}$ & $\mathrm{x}$ & $\mathrm{x}$ \\
\hline Observations & 4635 & 4635 & 4635 & 4635 & 4635 & 4635 \\
\hline R-squared & 0.89 & 0.89 & 0.89 & 0.89 & 0.89 & 0.89 \\
\hline
\end{tabular}

*Note: All models include Constant term and full set of Income, Age, Gender and Educational Controls.

Standard errors in parentheses, clustered by state.

+ significant at 10\%; * significant at $5 \%$; ** significant at $1 \%$ 
Table 6: Sensitivity Analyses

Dependent Variable: Log Per Capita Sales

\begin{tabular}{|c|c|c|c|c|c|c|}
\hline Variables & $\begin{array}{c}\text { Base Results } \\
\text { (1) }\end{array}$ & $\begin{array}{c}\text { AR(1) Error } \\
\text { Specification } \\
(2)\end{array}$ & $\begin{array}{c}\text { Include State*Qtr Fixed } \\
\text { Effects } \\
(3) \\
\end{array}$ & $\begin{array}{l}\text { Use Model* }{ }^{\star} \text { Quarters } \\
\text { with Greater than } \\
\text { Median Sales } \\
(4) \\
\end{array}$ & $\begin{array}{c}\text { Drop Months with Prius } \\
\text { and Civic Production } \\
\text { Constraints } \\
(5)\end{array}$ & $\begin{array}{c}\text { Drop Low Volume } \\
\text { Models (Insight, VUE, } \\
\text { GS450h) } \\
(6)\end{array}$ \\
\hline \multirow[t]{2}{*}{ log Per Capita Income } & 2.112 & 1.845 & 2.194 & 0.773 & 2.032 & 1.861 \\
\hline & $(0.457)^{\star \star}$ & $(0.449)^{\star \star}$ & $(0.452)^{\star \star}$ & $(0.425)+$ & $(0.453)^{\star \star}$ & $(0.492)^{\star \star}$ \\
\hline \multirow[t]{2}{*}{ log Mean Age } & -15.401 & -4.541 & -14.879 & -20.315 & -14.945 & -21.038 \\
\hline & $(3.437)^{\star \star}$ & $(1.783)^{\star}$ & $(3.378)^{\star \star}$ & $(3.223)^{\star \star}$ & $(3.457)^{\star \star}$ & $(3.887)^{\star \star}$ \\
\hline \multirow[t]{2}{*}{ Log Percent Female } & -1.081 & 0.281 & -0.873 & -8.844 & -2.373 & -7.289 \\
\hline & $(12.930)$ & $(9.473)$ & $(13.052)$ & $(13.803)$ & $(12.949)$ & $(12.873)$ \\
\hline \multirow[t]{2}{*}{ log Percent HS Graduate } & 1.064 & 1.642 & 1.083 & 1.602 & 0.877 & 0.532 \\
\hline & $(0.793)$ & $(0.797)^{\star}$ & $(0.770)$ & $(0.725)^{\star}$ & $(0.799)$ & $(0.834)$ \\
\hline \multirow[t]{2}{*}{ log Percent College Grad } & -0.157 & 0.040 & -0.152 & -0.213 & -0.170 & -0.507 \\
\hline & $(0.197)$ & $(0.197)$ & $(0.189)$ & $(0.150)$ & $(0.202)$ & $(0.200)^{\star}$ \\
\hline \multirow[t]{2}{*}{ log Retail Gasoline Price } & 0.712 & 0.583 & 0.607 & 0.698 & 0.804 & 0.632 \\
\hline & $(0.308)^{\star}$ & $(0.274)^{\star}$ & $(0.319)+$ & $(0.230)^{\star \star}$ & $(0.315)^{\star}$ & $(0.353)+$ \\
\hline \multirow[t]{2}{*}{ HOV access dummy } & -0.082 & -0.128 & -0.069 & -0.012 & -0.081 & 0.007 \\
\hline & $(0.059)$ & $(0.068)+$ & $(0.050)$ & $(0.054)$ & $(0.059)$ & $(0.054)$ \\
\hline \multirow[t]{2}{*}{ State Tax Incentive $(\$ 000)$} & 0.049 & 0.027 & 0.045 & 0.115 & 0.049 & 0.045 \\
\hline & $(0.026)+$ & $(0.026)$ & $(0.028)$ & $(0.021)^{\star \star}$ & $(0.027)+$ & $(0.028)$ \\
\hline \multirow[t]{2}{*}{ Constant } & 38.370 & 0.986 & 36.705 & 56.168 & 35.628 & 56.273 \\
\hline & $(15.705)^{\star}$ & $(0.355)^{\star \star}$ & $(15.237)^{\star}$ & $(16.864)^{\star \star}$ & $(15.695)^{\star}$ & $(17.604)^{\star \star}$ \\
\hline State*Model FE & $\mathrm{x}$ & $\mathrm{x}$ & $\mathrm{x}$ & $\mathrm{x}$ & $\mathrm{x}$ & $\mathrm{x}$ \\
\hline Time*Model FE & $\mathrm{x}$ & $\mathrm{x}$ & $\mathrm{x}$ & $\mathrm{x}$ & $\mathrm{x}$ & $\mathrm{x}$ \\
\hline Observations & 4781 & 4284 & 4781 & 2486 & 4659 & 3726 \\
\hline R-squared & 0.68 & 0.74 & 0.79 & 0.87 & 0.68 & 0.72 \\
\hline
\end{tabular}

Standard errors in parentheses, clustered by state and time.

+ significant at 10\%; * significant at 5\%; ** significant at $1 \%$ 